\title{
Mothers' Involvement: Children's Perception of Maternal Childrearing Practices
}

\author{
ZAHYAH HANAFI \\ Faculty of Cognitive Sciences and Education \\ Universiti Utara Malaysia
}

\begin{abstract}
The purpose of this study is to identify maternal childrearing practices (achievement values, monitoring, and discussion) among employed and unemployed Malaysian mothers. Generally, these mothers have similar levels of childrearing practices. They instill high achievement values, conduct consistent monitoring on their children, and carry out regular discussions with them. They only differ in terms of monitoring. Discussion, implications, recommendations, and suggestions for future study are included.
\end{abstract}

\begin{abstract}
ABSTRAK
Objektif kajian ini adalah untuk mengenal pasti tahap penglibatan ibu yang bekerja dan tidak bekerja dari segi nilai pencapaian, pengawasan, dan perbincangan. Secara keseluruhannya, kedua-dua golongan ini mempunyai tahap penglibatan yang tinggi untuk ketiga-tiga dimensi penglibatan. Namun demikian mereka hanya berbeza dari aspek pengawasan sahaja. Perbincangan, implikasi, cadangan, dan kajian turut dikemukakan.
\end{abstract}

\section{INTRODUCTION}

Over the years, the increasing number of Malaysian women in the work force may have had an impact on their childrearing practices. Although most women with children work, they still continue to bear primary responsibility for childrearing (Hochschild, 1989). The circumstances of mothers, the attitudes and expectations of mothers, and the distribution of time available have important implications on their children. They spent hours shopping, house cleaning, cooking, doing laundry, and childcare. Thus, these tasks they perform daily may leave an impact on their childrearing practices.

Research on family studies in Malaysia has yet to examine the consequences of working mothers balancing the demands of work and fam- ily life. Studies have not been clear in pointing out this shift in the role of a woman as a traditional homemaker to a career woman and its influence on family life, especially in childrearing practices. Thus, this study calls for an investigation of the research agenda that searches for consequences of maternal employment and maternal involvement.

The objectives of this study are: (1) to examine the level of achievement values, monitoring, and discussion among employed and unemployed mothers. (2) to investigate whether there is any relationship between the variables. This study is considered important for a number of reasons. First, the findings in this study will provide a guide in identifying the practices that will be included in a parenting program for employed and unemployed mothers. Secondly, the results will 
be disseminated to parents, teachers, and counselors to further understand the importance of conducting such a study.

The study used categorical scale which is most appropriate to identify the level of maternal involvement (Cohen, Manion, \& Morrison, 2001; Hair, Anderson, Tatham, \& Black, 1998; Black, 2001). Thus, the findings in this study will only reflect the maternal involvement of employed and unemployed mothers in this study and not on mothers in general.

The survey was conducted on children (girls and boys), excluding their parents. This was found to be the most common method used in measuring parental involvement (Seginer, 1983), as children were better in perceiving their parents' involvement than parents themselves (Paulson, Hill, \& Holmbeck, 1991; Paulson, 1994a). In addition, parents tend to perceive themselves as being more involved in parenting than their children (Schwatrz, Barton-Henry, \& Pruzinsky, 1985). Thus, children's perceptions would be more reliable in this study.

Mothers' involvement is defined in terms of achievement values, monitoring, and discussion. These dimensions measure general maternal practices. Achievement values refers to practices that are inclined towards academic performance, for example, aspirations, importance of homework, and going to university. Monitoring practices are geared towards rules pertaining to watching TV and outings. Discussion is defined as mother-child discussions on general matters pertaining to the child's daily life. Employed refers to jobs that generate income. The job could either be performed outside or inside the home (for example, baby-sitting).

The importance of family influence on various aspects of child development has been stressed in the Ecological Theory (Bronfenbrenner, 1986). According to the Ecological Theory, the child is placed in the center of the Ecological system (Microsystem) and the immediate influence will be from the child's parents. In this study it will be the mothers. The child will experience various interactive influences within this microsystem. Thus, the existence of strong reciprocal links between mothers and children can have positive influence. A lack of such links will have a negative impact on the child's development (Dauber \& Epstein, 1993).

\section{METHODOLOGY}

A total of 535 respondents were involved in this study. The respondents were all Form Five students, aged between 16-17 years, studying in three different secondary schools in a district in Kedah. From the 535 respondents, it was found that these respondents had 173 employed mothers and 359 unemployed mothers.

The schools were selected based on purposeful sampling to ensure the presence of Chinese students. As most of the schools in the district had more Malay students compared to Chinese, it was necessary to select schools with Chinese students. From the 535 respondents, there were 173 employed and 359 unemployed mothers. Three respondents did not report on their mother's working status.

The instrument used in this study is adopted from the parental involvement scale (Zahyah Hanafi, 2003), and is designed to assess maternal involvement from adolescents' perspectives. This instrument was previously adapted from the "Parental Involvement Scale" by Paulson (1994b). Separate subscales of maternal values towards achievement, monitoring, and discussion are created in keeping with the different ways maternal involvement is defined in the literature. There are 5 items for achievement values, 5 items for monitoring and 5 items for discussion (Table 1). To determine the level of these dimensions, the mode technique is used. The levels are then categorized into $1=$ low, $3=$ undecided, $5=$ high.

The English version of the questionnaire (Table 1) was then translated into Bahasa Malaysia for purposes of easy comprehension by respondents. The translation procedure is the backtranslation method. To ensure the reading levels do not impede respondent's ability to reliably complete the items, the instructions and individual items are read aloud by the Bahasa Malaysia teacher while the respondents read along silently.

In this study categorical rating scale is used. This will reflect all respondents assigned to the same category will be alike with respect to 
Table 1:

Maternal Involvement Items

\begin{abstract}
Achievement values:
1. My mother has high aspirations for my future.

2. My mother tries to get me to do my best on everything I do.

3. My mother thinks I should go to the university.

4. My mother thinks that getting ahead in life is very important.

5. My mother thinks homework is a very important part of school.
\end{abstract}

Monitoring:

6. My mother sets rules on the number of hours I can watch TV during school days.

7. It is okay with my mother if I do not follow certain rules.

8. My mother usually wants to know where I am going.

9. My mother makes most of the decisions about what I am allowed to do.

10. My mother expects me to be home at a certain time after school or in the evening.

Discussion:

11. My mother encourages me to talk with her on all matters.

12. My mother would rather I not tell her my troubles.

13. My mother expects me to do what she says without having to tell me why.

14. My mother takes an interest in my activities.

15. My mother usually tells me the reasons for rules.

some of the maternal involvement attributes (Nunnally, 1978). The anchor, $3=$ undecided, is included in the ordinal scale as the researcher feels that there could be respondents who actually feel that way and do not wish to be forced into agreeing or disagreeing (Ary, Jacobs, \& Razavieh, 2002). The "undecided" category could also refer to respondents who are unaware of the maternal practices and thus, are undecided whether the behavior existed or not. In addition, most social and behavioral sciences and education measurements are at best ordinal even though most researchers treat them as interval (Mason \& Bramble, 1997). To determine the level of maternal involvement, the mode technique is used to identify the most frequently cited anchor. This is done by inspection rather than by computation.

To meet the first objective of this study, a descriptive analysis of frequencies and percentages on respondents' profile, mothers' achievement values, monitoring and discussion practices are tabulated. The mode value (tri-modal) determined a distribution that occurred most frequently. In addition, the chi-square test would show whether there are differences between employed and unemployed mothers' achievement values, monitoring, and discussion level.

\section{FINDINGS}

Table 2 shows majority of employed mothers have secondary school education (41.6\%), followed by those with tertiary level (19.7\%), and primary $(17.9 \%)$. A small group of these mothers have no form of education at all (2.9\%). There are also respondents $(17.9 \%)$ who are unable to identify the educational level of their mothers.

On the other hand, there are 37.8 percent unemployed mothers with secondary school education, 33.9 percent primary schooling, 1.4 percent have no form of education at all and only 0.8 percent with tertiary education. Quite a proportion of the respondents $(25.8 \%)$ are unable to identify their mothers' educational level.

Based on this report, it could be concluded that there are more unemployed mothers with primary and secondary schooling (71.7\%) compared to employed mothers $(59.5 \%)$. On the other hand, there are more employed mothers with tertiary education (19.7\%) compared to unemployed mothers $(0.8 \%)$. 
Table 2 :

Frequency Distribution of Educational Level Among Employed and Unemployed Mothers

\begin{tabular}{lllllll}
\hline & $\begin{array}{l}\text { don't } \\
\text { know }\end{array}$ & $\begin{array}{c}\text { no } \\
\text { schooling }\end{array}$ & primary & secondary & tertiary & total \\
\hline Employed & 31 & 5 & & & & \\
& $(17.9)$ & $(2.9)$ & $(17.9)$ & $(41.6)$ & $(19.7)$ & \\
Unemployed & 93 & 5 & 122 & 136 & 3 & 359 \\
& $(25.9)$ & $(1.4)$ & $(34.0)$ & $(37.9)$ & $(0.8)$ & \\
\hline & 129 & 10 & 153 & 208 & 37 & 532 \\
& $(24.2)$ & $(1.9)$ & $(28.8)$ & $(39.0)$ & $(7.0)$ & \\
\hline
\end{tabular}

Note: Figures in parentheses indicate valid percentages

Objective: (1) To examine the level of achievement values, monitoring, and discussions among employed and unemployed mothers.

Table 3 :

Frequency Distribution of Maternal Childrearing Practices

\begin{tabular}{|c|c|c|c|c|}
\hline & low & high & undecided & total \\
\hline \multicolumn{5}{|l|}{ Achievement Values } \\
\hline Employed mothers & $\begin{array}{l}1 \\
(0.5)\end{array}$ & $\begin{array}{l}176 \\
(96.8)\end{array}$ & $\begin{array}{l}5 \\
(2.7)\end{array}$ & 182 \\
\hline \multirow[t]{2}{*}{ Unemployed mothers } & $\begin{array}{l}3 \\
(0.8)\end{array}$ & $\begin{array}{l}320 \\
(90.7)\end{array}$ & $\begin{array}{l}30 \\
(8.5)\end{array}$ & 353 \\
\hline & $\begin{array}{l}4 \\
(0.7)\end{array}$ & $\begin{array}{l}496 \\
(92.7)\end{array}$ & $\begin{array}{l}35 \\
(6.5)\end{array}$ & 535 \\
\hline \multicolumn{5}{|l|}{ Monitoring } \\
\hline Employed mothers & $\begin{array}{l}65 \\
(35.7)\end{array}$ & $\begin{array}{l}66 \\
(36.6)\end{array}$ & $\begin{array}{l}51 \\
(28.0)\end{array}$ & 182 \\
\hline \multirow[t]{2}{*}{ Unemployed mothers } & $\begin{array}{l}80 \\
(22.7)\end{array}$ & $\begin{array}{l}164 \\
(46.4)\end{array}$ & $\begin{array}{l}109 \\
(30.9)\end{array}$ & 353 \\
\hline & $\begin{array}{l}145 \\
(27.0)\end{array}$ & $\begin{array}{l}230 \\
(43.0)\end{array}$ & $\begin{array}{l}160 \\
(30.0)\end{array}$ & 535 \\
\hline \multicolumn{5}{|l|}{ Discussion } \\
\hline Employed mothers & $\begin{array}{l}47 \\
(25.8)\end{array}$ & $\begin{array}{l}67 \\
(36.8)\end{array}$ & $\begin{array}{l}68 \\
(37.4)\end{array}$ & 182 \\
\hline \multirow[t]{2}{*}{ Unemployed mothers } & $\begin{array}{l}75 \\
(21.2)\end{array}$ & $\begin{array}{l}131 \\
(37.1)\end{array}$ & $\begin{array}{l}147 \\
(41.6)\end{array}$ & 353 \\
\hline & $\begin{array}{l}122 \\
(22.8)\end{array}$ & $\begin{array}{l}198 \\
(37.0)\end{array}$ & $\begin{array}{l}215 \\
(40.2)\end{array}$ & 535 \\
\hline
\end{tabular}

Note: Figures in parentheses indicate valid percentages 
Overall, children perceived both employed and unemployed mothers as possessing high achievement values (Table 3). However, the Chi-square test shows no difference in both these mothers' achievement values. Mothers' monitoring practices are high and there are differences between these mothers' monitoring practices. Unemployed mothers (46.4\%) are perceived by their children to be more serious in monitoring compared to employed mothers (36.6\%). Similarly, children perceived their mothers as having high discussion level. However, there is no difference between both mothers' discussion level.

Objective: (2) To investigate whether there is any relationship between the variables. The Chi-square tests show no relationship between the variables except for unemployed mothers' educational level and achievement values. Even this relationship is low $(\mathrm{r}=.181, \mathrm{p}=.001)$.

\section{DISCUSSION OF THE FINDINGS}

The results in this study only reflect mothers' involvement with children in the three schools. Therefore, it should not be generalized to represent all Malaysian mothers. The objectives of this study are to identify the level of mothers' achievement values, monitoring, and discussion and to examine whether there is any difference between these variables.

The findings revealed children in this study perceived their mothers to have high achievement values, conduct consistent monitoring, and discussions with them. The findings indicate that mothers whether they are employed or unemployed are aware of the importance of education. This sense of awareness is again reflected when there is no significant difference between these mothers' achievement values. This may be true as studies have shown achievement values have been reported by children to be high among parents irrespective of parents socioeconomic status (Kaplan, Liu, \& Kaplan, 2000; Mickelson, 1990) and living in different geographical settings (Moller, 1997).

These achievement values could have been conveyed through mother-child interactions
(Table 1), where mothers may set high aspirations (Item 1), encourage the child to do the best in everything the child does (Item 2), expects the child to go to the university (Item 3), getting ahead in life is important (Item 4), and homework is an important part of school (Item 5). In addition, these achievement values practices could have been transmitted during mother-child daily discussions where mothers encourage children to talk on all matters (Item 11), explain to the children when they tell the children to do something (Item 13), take an interest in the child's activities (Item 14), and explain the rules that they sets (Item 15). These consistent mother-child discussions may be perceived by children as a mother's way of showing her interest in the child's daily life.

The present findings thus supports the belief that Asian parents are generally achievement oriented (Keith, T. Z., Keith, P. K., Quirk, K. J., Sperduto, J., Santillo, S., \& Killings, S. 1998; Marjoribanks, 2002; Mau 1995; Peng \& Wright, 1994). Since the respondents are in Form Five, an examination year, this could have initiated the high achievement values in this particular maternal practice.

Monitoring has been reported to be a common parenting practice among Asian parents and more prevalent among mothers (Paulson \& Sputa, 1996; Shek, 2000; Yau \& Smetana, 1996). This characteristic among mothers could be due to the nature of their role of being in charge of domestic affairs of childrearing (Shek, 1998, 2000). In this study, monitoring is the only dimension that showed a difference between the way employed and unemployed mothers conduct their monitoring practices. The children perceived unemployed mothers as conducting more monitoring on them compared to mothers who are employed. This difference could be attributed to the absence and presence of these two groups of mothers in the home.

With the lower educational level (Table 1), unemployed mothers may find difficulties in acquiring jobs. This may lead them to be full-time housewives instead. Since they are at home when the children are back from school, these mothers may have more time and opportunity to be with their children compared to mothers who are away working. Therefore, unemployed mothers can 
monitor more often. On the other hand, the working hours of employed mothers may have resulted in less time at home for monitoring. As a consequence, they face the constraint of finding time to monitor the whereabouts and activities of their children (Fatimah Abdullah, 1987).

The discussion dimension is identified as a source of stimulation in the home environment which mothers and children could use as a platform for daily interactions. In this study there is high mother-child discussion. Mothers can use this form of communication to listen to problems and difficulties as well as achievement, and provide a supportive role when schoolwork or relationships at school are problematic (Steinberg, 1996). Similarly, for mothers who spent more time on mother-child discussions, the more likely that their children would perceive it as a positive indication of mothers' interest in their learning (Trivette \& Anderson, 1995).

Parent-child discussion has also been reported to increase with age. For example, Gauvain and Huard (1999) found that during preschool years, children rarely initiate parent-child discussion. However, when the child reaches nine years old, she/he becomes more involved and this involvement increases towards adolescent. The topic of discussion too changes from daily activities into long-range plans, which extends further into the adolescents' future.

The study points to the fact that there is not much difference between employed and unemployed maternal practices. Even though unemployed mothers are found to have less educational levels compared to employed mothers there is no indicator showing that unemployed mothers instill less achievement values and conduct less discussion with their children. The only difference is in the way they monitor their children. The unemployed mothers are found to carry out more monitoring practices as they are present in the home most part of the day. Thus, the difference is due to the time factor.

\section{RECOMMENDATIONS}

This study could be looked upon as an initial step into identifying mothers' involvement in their children's life. No doubt this study did not try to relate these maternal practices to specific children's development but it has made us more aware of the level of childrearing practices among these two groups of mothers. Indirectly, it also tells us the type of mothers these children are living with.

Findings on parents with high achievement values have been reported to be the most important factor in raising children's academic achievement (Patrikakou, 1996). High monitoring (demand) skills have also been consistently related to children with better performance in school (Darling, 1999), less likely to play truant, unlikely to indulge in alcoholism, and delinquency in children and adulthood (Lamborn, Mounts, Steinberg, \& Dornbusch, 1991). Similarly, high mother-child discussion have also been found to relate to better academic achievement (Desimone, 1999; Moller, 1997), positive parenting style (Gauvian \& Huard, 1999), and higher interest in school (Trivette \& Anderson, 1995; Patrikakou, 1997). Thus, these practices are found to contribute to positive behaviors in children. As such, the importance of these parenting practices should be conveyed to parents so that they can be more focused in raising their child.

Based on the findings and discussion, the following recommendations are formulated for schools to play a more aggressive role in educating parents on the importance of getting involved in their children's daily lives.

The first step will be to implement parenting programs in schools. However, this step needs to be planned and implemented effectively. It will be appropriate to invite researchers to conduct a study to identify mothers that would participate in the program. It is from these findings that programs could be built to cater for the different levels of involvement.

A recommended sample for school-family program would be Form One students. The reasons being, first, these students are in their first year of secondary school. They are on the verge of entering early adolescence. For these students it is a transition period and they would need a lot of guidance and help in adapting to the new life style and school environment.

Second, parents too need to change their approach to childrearing as the children move into 
secondary school. Certain skills need to be emphasized while others may need lesser attention. It will also be the right time to get parents more involved in their children's learning as parents would generally feel that once their children step into secondary school, there is less need for them to be involved (Epstein, 1987; Snodgrass, 1991).

Third, studies have shown that in order for parenting skills to have an influence on learning, they have to be consistently instilled throughout the schooling years (Hoge, 1997; Trusty, 2000). This will mean starting from the first year of secondary schooling. Once parents are properly guided and taught the basic skills of parenting, it can be assumed that after two years the parenting practices will have had an impact on the child's development. Thus, schools need to play an aggressive role in ensuring parents are monitored and that parents meet the expectations of the program.

Parenting programs will benefit not only adolescents and the school but also parents (Noller $\&$ Taylor, 2001). The ability to be able to engage in one's child development at home will boost parents' sense of efficacy (Hoover-Demsey, Bassler, \& Brissie, 1992). It is important that parents feel they can contribute to their child's positive development as this will motivate them to be more involved.

Since this study did not look at maternal practices and its influence on the development of children, it is suggested that future studies examine parenting practices and its influence on children's learning and psychological development. These studies could either be conducted as a case study in the case of initiating a parenting program or it could be conducted with the intention of exploring the parenting practices of parents in general. Such studies will provide a clearer picture of Malaysian parents' involvement in their children's development.

\section{REFERENCES}

Ary, D., Jacobs, L. C., \& Razavieh, A. (2002). Introduction to research in education. Australia: Wadsworth Thompson Learning.
Black, K. (2001). Business statistics: contemporary decision making. ( ${ }^{\text {rd }}$ ed.) Australia: South-Western College Publishing, p. 6.

Bronfenbrenner, U. (1986). Ecology of the family as a context for human development: research perspectives. Development Psychology, 22, 723-742.

Cohen, L., Manion, L., \& Morrison, K. (2001). Research methods in education. ( $5^{\text {th }} \mathrm{ed}$.) London: Routledge Falmer, p. 318.

Darling, N. (1999). Parenting style and its correlates. Eric Digest. Champaign: Eric Clearinghouse on Elementary and early Childhood Education, University of Illinois (ED 427 896). Org/pubs/digests/ 1999/darlin99.html" http://ericeece. org/ pubs/digests/1999/darlin99.html

Dauber, S. L., \& Epstein, J. L. (1993). Parents' attitudes and practices of involvement in inner-city elementary and middle schools. In N.F. Chavkin (Ed.). Families and schools in a pluralistic society (pp. 53-71). Albany New York: State University of New York Press.

Desimone, L. (1999). Linking parent involvement with student achievement: do race and income matter? Journal of Educational Research, 93 (1),11-31.

Epstein, J. L. (1987). Parent involvement. what research says to administrators? Education and Urban Society, 19, 119-136.

Fatimah, Abdullah. (1987). Wanita yang bekerja dan pengurusan rumah tangga. Jurnal Antropologi dan Sosiologi, 15, 75-91.

Gauvian, M., \& Huard, R. D. (1999). Family interaction, parenting style and the development of planning: a longitudinal analysis using archival data. Journal of Family Psychology, 13 (1), 75-92.

Hair, F. H., Anderson, R. E., Tatham, R. L., \& Black, W. C. (1998). Multivariate data analysis. ( $5^{\text {th }}$ ed.). Prentice-Hall : International, Inc. 
Hochschild, A. (1989). The second shift. New York: Avon.

Hoge, D. R. (1997). Four family process factors predicting academic achievement in sixth and seventh grade. Educational Research Quarterly, 21,(2), 27-42.

Hoover-Demsey, K. V., Bassler, O. C., \& Brissie, J. S. (1992). Explorations in parentschool relations. The Journal of Educational Research, 85, 287-294.

Kaplan, D., Liu, X., \& Kaplan, H. B. (2000). Family structure and parental involvement in the intergenerational parallelism of school adversity. Journal of Educational Research, 93 (4), 235-245.

Keith, T. Z., Keith, P. K., Quirk, K. J., Sperduto, J., Santillo, S., \& Killings, S. (1998). Longitudinal effects of parental involvement on high school grades: Similarities and differences across gender and ethnic groups. Journal of School Psychology, 36 (3), 335-363.

Lamborn, S. D., Mounts, N. S., Steinberg, L., \& Dornbusch, S. M. (1991). Patterns of competence and adjustment among adolescents from authoritative, authoritarian, indulgent, and neglectful families. Child Development, 62, 1049-1065.

Marjoribanks, K. (2002). Family background, individual and environmental influences on adolescents' aspirations. Educational Studies, 28 (1), 33-46.

Mason, E. J., \& Bramble, W. J. (1997). Research in education and the behavioral sciences: concepts and methods. Madison: Brown \& Benchmark.

Mau, Wei-Cheng. (1995). Educational planning and academic achievement of middle school students: a racial and cultural comparison. Journal of Counselling and Development, 73 (5), 518-527.
Mickelson, R. A. (1990). The attitude-achievement paradox among black adolescents. Sociology of Education, 63 (1), 44-61.

Moller, V. (1997). Home environment and educational achievement among high-school pupils living in three-generation urban Black households. South African Journal of Sociology, 26 (3), 87-97.

Noller, P., \& Taylor, T. (2001). Parent education and family relations. Family Relations. 196-200.

Nunnally, J. C. (1978). Psychometric Theory. New York: McGraw-Hill Book Company.

Patrikakou, E. N. (1996). Investigating the academic achievement of adolescents with learning disabilities: a structural modeling approach. Journal of Educational Psychology, 88 (3), 435-450.

(1997). A model of parental attitudes and the academic achievement of adolescent. Journal of Research and Development in Education, 31, 7-26.

Paulson, S. E. (1994a). Relations of parenting style and parental involvement with ninth-grade students'achievement. Journal of Early Adolescence, 14, 250-276.

Paulson, S. E. (1994b). Construction and validation of parenting style and parental involvement scales. Ball State University.

Paulson, S. E., Hill, J. P., \& Holmbeck, G. N. (1991). Distinguishing between perceived closeness and parental warmth in families with seventh grade boys and girls. Journal of Early Adolescence, 11 (2), 276-293.

Paulson, S. E., \& Sputa, C. L. (1996). Patterns of parenting during adolescence: Perceptions of adolescents and parents. Adolescence, 31 (122), 369-382. 
Peng, S. S., \& Wright, D. (1994). Explanation of academic achievement of Asian American students. Journal of Educational Research, 87, 346-352.

Schwartz, J. C., Barton-Henry, M. L., \& Pruzinsky, T. (1985). Assessing childrearing behaviors: a comparison of ratings made by mother, father, child and sibling on the CRPBI. Child Development, 56, 462-479.

Seginer, R. (1983). Parents' educational expectations and children's academic achievement: a literature review. Merrill-Palmer Quarterly, 29, 1-23.

Shek, D. T. L. (2000). Differences between fathers and mothers in the treatment of, and relationship, with their teenage children: Perceptions of Chinese adolescents. Adolescence, 35, 135-175.

(1998). Adolescents' perception of paternal and maternal parenting styles in a Chinese context. Journal of Psychology, 132 (5). 527-538.

Snodgrass, D. M. (1991). The parent connection. Adolescence, 26, 83-87.
Steinberg, L. (1996). Beyond the classroom: why school reform has failed and what parents need to do. New York: Simon \& Schuster.

Trivette, P., \& Anderson, E. (1995). The effects of four components of parental involvement on eighth grade students achievement: structural analysis of Nels-88 data. School Psychology Review, 24 (2), 299318 .

Trusty, J. (2000). High educational expectations and low achievement: stability of educational goals across adolescence. Journal of Educational Research, 93 (6), 356366.

Yau, J., \& Smetana, J. G. (1996). Adolescent-parent conflict among Chinese adolescents in Hong Kong. Child Development, 67, 1262-1275.

Zahyah Hanafi. (2003). Relationships between socio-economic status, parental involvement, parenting style, and academic achievement. Unpublished $\mathrm{PhD}$ thesis. Universiti Utara Malaysia. 